\title{
Evict or infect? Managing populations of the large pine weevil, Hylobius abietis, using a bottom-up and top-down approach
}

\author{
Aoife B. Dillon *, Colm P. Moore, Martin J. Downes, Christine T. Griffin \\ Department of Biology and Institute of Bioengineering and Agroecology, National University of Ireland Maynooth, Maynooth. Co. Kildare, Ireland \\ Received 5 November 2007; received in revised form 8 January 2008; accepted 9 January 2008
}

\begin{abstract}
Hylobius abietis is the most important pest of replanted coniferous sites in Northern Europe, where feeding by adult weevils can result in up to $100 \%$ mortality of seedlings. Field trials were conducted with the aim of reducing $H$. abietis populations developing in Sitka spruce stumps by increasing pressure from natural enemies (top-down pressure), and reducing the quality of stumps for development (bottom-up pressure). Topdown pressure was applied through inundative treatment of stumps with entomopathogenic nematodes (Heterorhabditis downesi or Steinernema carpocapsae). Bottom-up pressure was applied by treating stumps with the wood colonising fungus Trichoderma koningii. Natural levels of parasitism of $\mathrm{H}$. abietis by the parasitoid Bracon hylobii and the effect of applied agents on B. hylobii were also investigated. Heterorhabditis downesi parasitised more immature weevils than $S$. carpocapsae, and significantly reduced numbers of adults emerging from stumps compared to controls. Entomopathogenic nematodes did not significantly impact on populations of $B$. hylobii, and over three sites the effects of both agents were additive. Stumps modified by application of the fungus (bottom-up pressure) did not have fewer $\mathrm{H}$. abietis developing in, or emerging from them; however, development of $H$. abietis was more advanced in these stumps, and the success of natural enemies was differentially affected. T. koningii facilitated B. hylobii while having the opposite effect on entomopathogenic nematodes, suggesting that it affected the outcome of competition between the nematodes and the parasitoid.
\end{abstract}

(C) 2008 Elsevier B.V. All rights reserved.

Keywords: Habitat manipulation; Hylobius; Integrated pest management; Entomopathogenic nematodes; Additive; Parasitoid

\section{Introduction}

Under natural forest conditions the large pine weevil, Hylobius abietis L. (Coleoptera: Curculionidae), breeds in damaged or fallen trees and insect numbers are controlled by the availability of suitable breeding sites. In intensively managed coniferous forests, the practice of clear felling large tracts of forest has presented $H$. abietis with effectively unlimited stumps in which to breed. Female weevils lay their eggs on, or near, stumps of recently felled coniferous trees. Larvae feed under the bark of the stump and develop into adults in 1-3 years (Bakke and Lekander, 1965; Norlander et al., 1997). Adult weevils emerging from stumps feed on woody plants, including young transplants. In the first few years following planting up to $100 \%$ of seedlings on restocking sites in the UK can be killed due to adult weevil feeding (Heritage

\footnotetext{
* Corresponding author. Tel.: +35316285222x3139; fax: +35317083845. E-mail address: Aoifebdillon@gmail.com (A.B. Dillon).
}

and Moore, 2001). Chemical insecticides are routinely used to protect seedlings from weevil damage (Langstrom and Day, 2004).

Competition for oviposition sites (stumps) is important in controlling populations of bark and wood boring beetles, including H. abietis (Eidmann, 1979; Okland and Berryman, 2004). Destruction of breeding sites was practised historically in many countries as the principal method of reducing the number of adult $H$. abietis emerging onto a site (Elton et al., 1964). Eidmann (1979) reported that where stumps were removed, confining weevil development to torn roots and stumps felled during forest thinning, $H$. abietis populations could be reduced by up to $50 \%$. Physical removal of stumps can result in soil compaction and increased siltation of waterways, so is not ideal from an environmental perspective. An alternative to physical stump destruction is to mask the volatiles emitted from the stumps, or modify the stumps to reduce their suitability for $H$. abietis oviposition and larval development. One approach to this would be to treat stumps with fast growing microorganisms at the time of felling. 
A similar technique is applied to the control of an important tree pathogen, Heterobasidion annosum (Fr.) Bref. (Basidiomycete), the main cause of root and butt rot in conifers in Northern Europe. The principal method of biological control of this pathogen is to prevent infection by treating freshly cut stumps with the wood decay fungus Phlebiopsis gigantea (Fr.) Julich (Basidiomycete). A number of other fungi including Trichoderma species (Hypocreales, Hypocreaceae) have also been considered (Berglund et al., 2005; Holdenrieder and Greig, 1998; Nicolotti and Varese, 1996; Kallio and Hallaksela, 1979). Trichoderma species are cosmopolitan in soil and on decaying wood. Although Trichoderma species are saprophytic fungi that modify wood, they do not dramatically degrade it (Klein and Eveleigh, 1998). Fungi that colonise conifer stumps may influence the success of $H$. abietis. In laboratory trials, Skrzecz (1996) reported that pine branches treated with $P$. gigantea were not accepted as oviposition sites by female $H$. abietis. The number and duration of visits by adult $H$. abietis to branches colonised by $P$. gigantea and Trichoderma harzianum Tul. were lower than controls, suggesting that avoidance may be in response to non-specific volatiles released during fungal growth (Skrzecz and Moore, 1997). Adult H. abietis are attracted onto a site by the volatiles such as monoterpenes and ethanol released by felling (Nordlander, 1987; Nordlander et al., 1986), therefore a fungal treatment that modifies the volatile blend emitted by the stump may reduce the attractiveness and/or suitability of stumps as $H$. abietis breeding sites.

Bottom-up and top-down forces act together on herbivore populations, and the success of parasitoids and entomopathogenic nematodes may be influenced by herbivore host plant quality (Price et al., 1980; Barbercheck, 1993; Jaworska, 1998; Kruse and Raffa, 1999). Two important natural enemies of $H$. abietis that could be affected by stump modification are entomopathogenic nematodes (EPN) and the gregarious ectoparasitoid Bracon hylobii Ratzeburg (Hymenoptera: Braconidae). The latter parasitises $H$. abietis larvae exclusively and is the principal natural control agent of H. abietis (Kenis et al., 2004), while EPN are the only biological control agents that have been employed on a semi-operational scale against $H$. abietis (Torr et al., 2005).

EPN of the rhabditid genera Steinernema and Heterorhabditis are insect parasites that have been successfully used to control several economically important insect pests (Grewal et al., 2005). The pathogenicity of the nematode genera is partly due to their symbiotic association with bacteria of the genera Xenorhabdus and Photorhabdus (Forst et al., 1997). The nonfeeding infective juveniles (IJs) actively seek out insects in the soil. The IJs enter the insects through their natural openings and, in the case of Heterorhabditis, through the cuticle. Following penetration into the insect haemocoel, the IJs release their symbiotic bacteria from their guts, while suppressing the insects' immune responses. Insect death typically occurs after 2-3 days.

EPN have primarily been applied against the sedentary immature $H$. abietis developing in the stumps, with a view to suppressing the population of adult weevils emerging on a site
(Brixey et al., 2006; Dillon et al., 2006; Torr et al., 2007). Steinernema carpocapsae Weiser is deployed on a commercial scale in Britain. Our trials have shown population suppression in pine is best achieved using Heterorhabditis downesi Stock, Griffin and Burnell (Dillon et al., 2006, 2007). H. downesi has not previously been tested against $H$. abietis developing in spruce stumps.

There were three objectives in these trials. The first objective was to reduce $H$. abietis populations developing in, and emerging from, Sitka spruce stumps by increasing pressure from natural enemies (top-down pressure), and reducing the quality of stumps in which the immature weevils develop (bottom-up pressure). Top-down pressure was applied through inundative treatment of stumps with EPN (S. carpocapsae or $H$. downesi). Bottom-up pressure was applied by treating the stumps with a fungus (T. koningii Oudem) at the time of felling, with the aim of making stumps unsuitable for $H$. abietis breeding. The fungus used in this trial ( $T$. koningii strain S28A1) was chosen based on its negative impact on pine weevil development and repellence of adults in laboratory assays (Creevey, 1999). The second objective was to determine whether T. koningii affected nematode parasitism of $H$. abietis, as Armendariz et al. (2002) reported possible facilitation of $S$. carpocapsae by $P$. gigantea in the laboratory. The third objective was to investigate whether stump treatment impacted on the native parasitoid B. hylobii. The numbers of weevils harbouring the parasitoid were recorded in untreated stumps and stumps to which the fungus and/or EPN were applied.

\section{Materials and methods}

\subsection{Experimental sites}

There were four field trials, one each in 2004 and 2005, and two in 2006 (Table 1). The 2004 and 2005 trials tested nematodes only, while the 2006 trials included nematodes, the wood colonising fungus T. koningii S28A1, and a combination of both treatments. Stumps were Sitka spruce (Picea sitchensis Carr) on mineral soil. Irish forestry distinguishes between peat and mineral soils. Peat is where a layer of raw humus has accumulated, and other soils are mineral. Soils in the study area are base poor, derived mainly from granite, schist and quartzite. Detailed soil analysis was not performed. Nematodes were applied in the second week of June in each trial, 18 (2005) or 23 (2004 and 2006) months after felling. The fungus was applied to stumps within one week after felling in 2004. Trials were assessed by destructive sampling, and/or by recording emergence of adult weevils (Table 1). The experiments were set out in a randomised block design, with each block containing 1 replicate (stump) of each treatment, except the 12month sampling at Annalecka where each block contained 3 fungal-treated and 3 control stumps.

\subsection{Nematodes}

Two nematode species were tested, commercially produced S. carpocapsae All strain (Koppert, Holland) and laboratory 
Table 1

Site details, experimental design and assessment method

\begin{tabular}{|c|c|c|c|c|c|c|c|c|}
\hline \multirow[t]{2}{*}{ Site name, coordinates, elevation } & \multirow[t]{2}{*}{ Felling date } & \multirow[t]{2}{*}{ Year of trial $^{\mathrm{a}}$} & \multicolumn{4}{|c|}{$\begin{array}{l}\text { Treatment and number of stumps/ } \\
\text { treatment }\end{array}$} & \multirow[t]{2}{*}{ Assessment } & \multirow[t]{2}{*}{ Sampling date } \\
\hline & & & $\mathrm{C}$ & $\mathrm{N}$ & $\mathrm{F}$ & $\mathrm{N}+\mathrm{F}$ & & \\
\hline \multirow[t]{2}{*}{ Ballinagee, $53^{\circ} 03^{\prime} \mathrm{N} 006^{\circ} 26^{\prime} \mathrm{W}, 425 \mathrm{~m}$} & $07 / 2002$ & 2004 & 20 & 20 & - & - & In stump & $07 / 2004$ \\
\hline & & & 16 & 16 & - & - & Emergence & 07/2004-09/2005 \\
\hline \multirow[t]{2}{*}{ Oakwood, $53^{\circ} 03^{\prime} \mathrm{N} 006^{\circ} 28^{\prime} \mathrm{W}, 4 \mathrm{~m}$} & $12 / 2003$ & 2005 & 20 & 20 & - & - & In stump & $07 / 2005$ \\
\hline & & & 20 & 20 & - & - & Emergence & $07 / 2005-09 / 2006$ \\
\hline \multirow[t]{2}{*}{ Annalecka, $53^{\circ} 03^{\prime} \mathrm{N} 006^{\circ} 26^{\prime} \mathrm{W}, 300 \mathrm{~m}$} & $07 / 2004$ & 2006 & 12 & - & 12 & - & In stump & $07 / 2005$ \\
\hline & & & 5 & 5 & 5 & 5 & In stump & $07 / 2006$ \\
\hline Glendalough, $53^{\circ} 00^{\prime} \mathrm{N} 006^{\circ} 19^{\prime} \mathrm{W}, 300 \mathrm{~m}$ & $07 / 2004$ & 2006 & 30 & 15 & 15 & 15 & Emergence & 07/2006-09/2006 \\
\hline
\end{tabular}

Treatment $\mathrm{N}=$ nematode (Steinernema carpocapsae or Heterorhabditis downesi), $\mathrm{F}=$ fungus (Trichoderma koningii), $\mathrm{N}+\mathrm{F}=$ nematodes and fungus, $\mathrm{C}=$ control. Control stumps were untreated, except on the Glendalough site where there were 2 control treatments-an untreated control and a beech sawdust/nutrient control ( $n=15$ for each control treatment in Glendalough).

a Year of nematode application.

produced $H$. downesi $\mathrm{K} 122$. S. carpocapsae was supplied in a wettable powder formulation less than a week before use and stored at $9{ }^{\circ} \mathrm{C}$ until required. On the day of application the product was mixed with water to a concentration of 7 million $\mathrm{IJ} / \mathrm{L}$. H. downesi was produced in late instar larvae of the wax moth Galleria mellonella L. at $20{ }^{\circ} \mathrm{C}$ (Woodring and Kaya, 1988; Dillon et al., 2006) and prepared to the same concentration on the day of application. Nematodes were transported to the field sites in 5-L bottles, which were shaken regularly to aerate the suspension.

Five hundred $\mathrm{ml}$ of nematode suspension was applied around each nematode-treated stump. The needle litter was removed and the nematode suspension poured onto the soil around the stump in a band approximately $5 \mathrm{~cm}$ wide. The litter was replaced to protect the nematodes against ultraviolet radiation and desiccation. Control stumps were left untreated.

\subsection{Fungus}

T. koningii strain S28A1 (CBS Fungal Biodiversity Centre accession number 121935) was maintained on malt extract agar (MEA) slopes at $4{ }^{\circ} \mathrm{C}$. The substrate for fungal growth consisted of beech sawdust (passed through an $8 \mathrm{~mm}$ sieve) in a nutrient broth. Broth ( $2 \%$ peptone $+2 \%$ sucrose, w/v) was added to the sieved sawdust at a volume ratio of $1: 1.25$ (sawdust:nutrient) and mixed thoroughly. Aliquots $(0.4 \mathrm{~kg})$ of beech/nutrient substrate were placed in autoclave bags, sealed and autoclaved at $121{ }^{\circ} \mathrm{C}$ for $20 \mathrm{~min}$. Cooled bags were inoculated under sterile conditions with five $10 \mathrm{~mm}$ agar discs from MEA cultures that had been grown at $20{ }^{\circ} \mathrm{C}$ for 14 days. Bags were re-sealed and incubated at $20{ }^{\circ} \mathrm{C}$ for 21 days. Inoculated bags were shaken periodically to ensure uniform distribution of the fungus throughout the substrate.

Five hundred milliliters of water was added to each autoclave bag immediately prior to application and mixed to form a viscous paste. One bag was used to treat each stump. The fungus was applied at 2 sites (Annalecka and Glendalough). Inoculum was applied around the circumference of the cut surface of the stumps. T. koningii was tested with and without each species of nematode (Table 1). At Annalecka control stumps received neither fungus nor nematodes. At Glendalough there were 2 control treatments: an untreated control and a beech sawdust/nutrient control.

\subsection{Assessment of $H$. abietis development and parasitism within stumps}

At Annalecka stumps were destructively sampled 12 or 24 months after application of the fungus. The second sampling date corresponded to 1 month after nematode application. Stumps at Oakwood and Ballinagee were destructively sampled 1 month after nematode application. Brash and soil were cleared from the stump and associated roots to a distance of $70 \mathrm{~cm}$. A chisel was used to remove the bark and excavate pupal chambers in the timber. The numbers of weevil larvae, pupae and immature adults per stump were counted. Insects parasitised by nematodes were recognised by characteristic colour changes. The percentage of $H$. abietis parasitised by the larval parasitoid B. hylobii was also recorded.

\subsection{Insect emergence}

Stumps were covered with alcohol and turpentine baited insect traps designed to catch emerging $H$. abietis adults. A trap consisted of a black cotton tent supported by a bamboo tripod, topped with a clear plastic trap bottle, with its skirt end buried in the ground (Dillon et al., 2006). Traps were erected 7 weeks after nematode application in Ballinagee and Oakwood. Adult $H$. abietis were collected in weeks 9, 11, 13, and 15 after nematode application and, in addition either in weeks 17, 24, 45, 47, 52, 54, 61 and 63 (Ballinagee), or weeks 18, 21, 52, 56, 60 and 65 (Oakwood). In Glendalough emergence traps were erected 4 weeks after nematode application and checked 6, 10 and 14 weeks after nematode application. Traps were not reerected for a second season at Glendalough due to the low numbers of weevils emerging from the stumps in the first season. 


\subsection{Data analysis}

Routine statistics were performed using MINITAB Release 14 for Windows (Minitab Inc., 2003). Significance levels were taken at $P<0.05$, unless otherwise stated. Data were tested for normality using the Anderson Darling test and, where found to be non-normal, data were transformed. Emergence data were transformed using a square root transformation, with the exception of emergence in Glendalough where data could not be normalised. Percentage parasitism data were transformed using the arcsine square root transformation. More than two treatments were compared using General Linear Model ANOVA followed by pairwise comparisons (Tukey's test; alpha $=0.05)$. Emergence data for Glendalough was analysed separately from Ballinagee and Oakwood, as data for Glendalough was only recorded over a single season. Emergence in Glendalough was compared using KruskalWallis Test. H. abietis population structure was compared using $\chi^{2}$ (on three nematode sites) or Fishers Exact Test (with and without fungus).

\section{Results}

\subsection{H. abietis population structure and natural mortality in control stumps}

Destructive sampling in 3 sites in July, 19-24 months after felling, allowed the population structure to be examined. In the control stumps, the proportion of weevil larvae, pupae and adults differed significantly among the 3 sites (Table 2; $\chi^{2}=95.57,4$ d.f., $\left.P<0.001\right)$. In Oakwood, weevils were at a more advanced stage of development, followed by Ballinagee and then Annalecka. At Oakwood and Ballinagee less than 30\% of weevils were larvae at the time of sampling. Adult weevils were present in stumps on both sites (30 and 4\%, respectively). In Annalecka there were no adult weevils in the stumps and $84 \%$ of the population was still larvae. Over the 3 sites, natural mortality in control stumps was $20 \%$. The principal cause of mortality (15\%) was the parasitoid B. hylobii, while a small percentage of insects died of unknown causes $(5 \%)$.

\subsection{Parasitism of $H$. abietis by applied EPN and the native parasitoids B. hylobii (in the absence of T. koningii)}

The impact of EPN on H. abietis was assessed in two ways: by destructive sampling of stumps 4 weeks after nematode application and by trapping emerging adults. Destructive

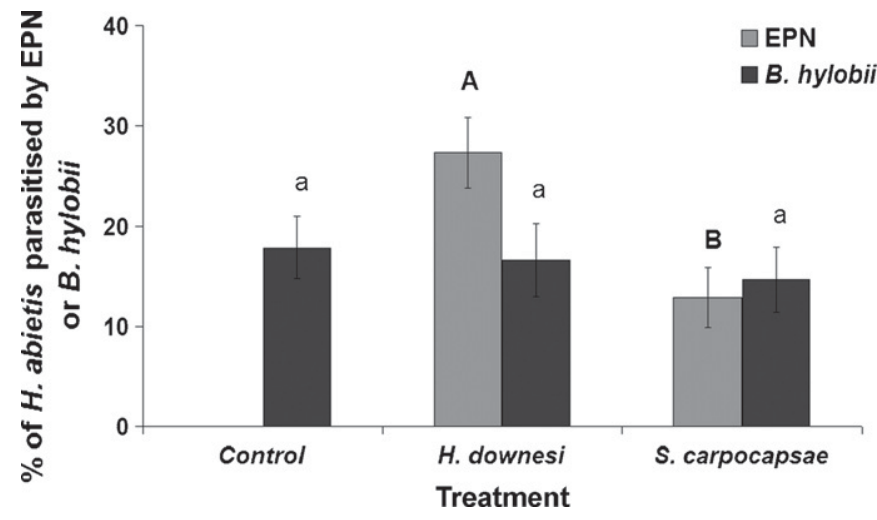

Fig. 1. Percentage (mean \pm S.E.) of Hylobius abietis parasitised by either EPN (Steinernema carpocapsae or Heterorhabditis downesi) or Bracon hylobii. Spruce stumps were treated with 3.5 million nematodes/stump 18 (1 site) or 23 months ( 2 sites) after felling. Stumps were destructively sampled 1 month after application of nematodes. Different letters above a column indicate significant differences in parasitism by EPN (uppercase) or by B. hylobii (lowercase) (ANOVA, $P<0.05)$.

sampling was carried out on three sites (Table 1). Similar numbers of $H$. abietis were recovered from stumps treated with $H$. downesi, S. carpocapsae and control stumps $(9.69 \pm 1.53$, $12.27 \pm 1.60$ and $12.69 \pm 2.03$, respectively) when stumps were destructively sampled $\left(F_{2,126}=1.00, P>0.05\right)$. The number of $H$. abietis developing in the stumps differed significantly among sites $\left(F_{2,126}=22.61, P<0.001\right)$, ranging from 6 to 21 weevils/stump (Table 2). There was no interaction between stump treatment and site $\left(F_{4,126}=1.05, P>0.05\right)$.

No weevils were parasitised by nematodes in any of the control stumps. The percentage of weevils parasitised by $H$. downesi was significantly higher than by $S$. carpocapsae $\left(27.31 \pm 3.58\right.$ and $12.56 \pm 2.93$, respectively; $F_{1,75}=9.86$, $P<0.01$ ) (Fig. 1). Parasitism by EPN did not vary among sites and there was no interaction between nematode species and site $\left(F_{2,75}=2.96, P>0.05\right.$ and $\left.F_{2,75}=0.75, P>0.05\right)$.

The percentage of weevils parasitised by $B$. hylobii varied among the 3 destructively sampled sites $\left(F_{2,}, 111=16.37\right.$, $P<0.001)$, with lower values recorded in Ballinagee $(6.0 \pm 1.3)$ than in Oakwood $(28.1 \pm 3.7)$ or Annalecka $(19.4 \pm 4.6)$. Treatment of stumps with nematodes did not significantly affect $B$. hylobii parasitism (Fig. 1), and there was no interaction between treatment and site $\left(F_{2,111}=1.16\right.$, $P>0.05$ and $\left.F_{4,111}=1.03, P>0.05\right)$.

When total parasitism (by B. hylobii and EPN) was analysed the percentage of weevils parasitised varied among the 3 sites $\left(F_{2,111}=5.15, P<0.01\right)$, and was significantly affected by

Table 2

Number of live Hylobius abietis in control spruce stumps on 3 sites in July 19-24 months after felling, and average number of weevils (live and dead) per stump across nematode and control treatments on each site

\begin{tabular}{llrcrrr}
\hline Site & Larvae & Pupae & Adults & $\begin{array}{l}\text { Total number } \\
\text { of insects }\end{array}$ & $\begin{array}{l}\text { Range } \\
\begin{array}{l}\text { Mean ( } \pm \text { S.E.) number } \\
\text { of weevils/stump }\end{array}\end{array}$ \\
\hline Ballinagee & 21 & 46 & 3 & 70 & $0-20$ & 20 \\
Oakwood & 88 & 140 & 98 & 326 & $0-53$ & 20 \\
Annalecka & 47 & 9 & 0 & 56 & $4-19$ & 5 \\
\hline
\end{tabular}

Different letters indicate significant differences between values (ANOVA, Tukey at $P<0.05$ ). 
Table 3

Number (mean \pm S.E.) of immature Hylobius abietis developing in spruce stumps at Annalecka at the time of stump destruction 12-24 months after felling.

\begin{tabular}{lll}
\hline & No. weevils per stump \\
\hline Stump treatment & 12 months & 24 months \\
With Trichoderma koningii & $12 \pm 3 \mathrm{~A}$ & $22 \pm 3 \mathrm{~B}$ \\
Without Trichoderma koningii & $9 \pm 3 \mathrm{~A}$ & $21 \pm 4 \mathrm{~B}$ \\
\hline
\end{tabular}

Data are for all treatments combined (no-nematode stumps at 12 months sampling and no nematode, H. downesi and S. carpocapsae-treated stumps at 24 month sampling). Different letters within the table indicate significant differences between values (ANOVA, Tukey at $P<0.05$ ). $N=12$ and 15 stumps after 12 and 24 months, respectively.

stump treatment (nematodes or no nematodes) $\left(F_{2,111}=6.58\right.$, $P<0.01)$. Total parasitism in $H$. downesi-treated stumps $(43.9 \pm 4.3)$ was significantly higher than in $S$. carpocapsaetreated or control stumps $(27.2 \pm 3.8$ and $17.8 \pm 3.1$, respectively) $(P<0.05)$, and there was no significant difference between the latter treatments. There was no interaction between treatment and site $\left(F_{4,111}=0.46, P>0.05\right)$.

\subsection{Effect of the fungus T. koningii on H. abietis within stumps (Annalecka only)}

At Annalecka, fungal-treated and control stumps were destructively sampled 12 and 24 months after felling. Application of $T$. koningii did not reduce the number of $H$. abietis developing in the stumps $\left(F_{1,50}=0.32, P>0.05\right.$; Table 3). Year after felling had a significant effect $\left(F_{1}\right.$, $50=15.37, P<0.001)$, with approximately twice as many weevils in year 2 as year 1 (Table 3 ). There was no interaction between the year and fungus $\left(F_{1,50}=1.77, P>0.05\right)$. The majority of live weevils were still larvae in fungal-treated (44/ 64 insects) and control stumps (47/55 insects) 24 months after felling. A greater proportion of $H$. abietis had pupated in fungal-treated stumps compared to the population in control stumps $\left(\chi^{2}=4.59,1\right.$ d.f., $\left.P<0.05\right)$.

\subsection{Parasitism of H. abietis by applied EPN and native parasitoids in T. koningii-treated stumps (Annalecka only)}

At Annalecka it was possible to examine interactions among all three agents: EPN and fungus applied to stumps, and the native $B$. hylobii. Stump assessment showed evidence that $T$. koningii affected parasitism by EPN and B. hylobii differentially, inhibiting the performance of EPN and enhancing that of B. hylobii (Fig. 2). Fewer weevils were parasitised by EPN in fungal-treated stumps than in no-fungus stumps $\left(F_{1,16}=3.48\right.$, $P=0.08$ ) (Fig. 2a). More $H$. abietis were parasitised by $H$. downesi than by $S$. carpocapsae $\left(F_{1,16}=16.64, P<0.001\right)$; there was no interaction between nematodes and fungus $\left(F_{1}\right.$, $16=0.11, P=0.74)$. Suspecting that at least some of the $B$. hylobii parasitised $H$. abietis may have been unavailable to EPN, we explored the effect of the fungus on EPN parasitism by examining the subset of weevils that were not parasitised by $B$. hylobii. When only those weevils were considered, the
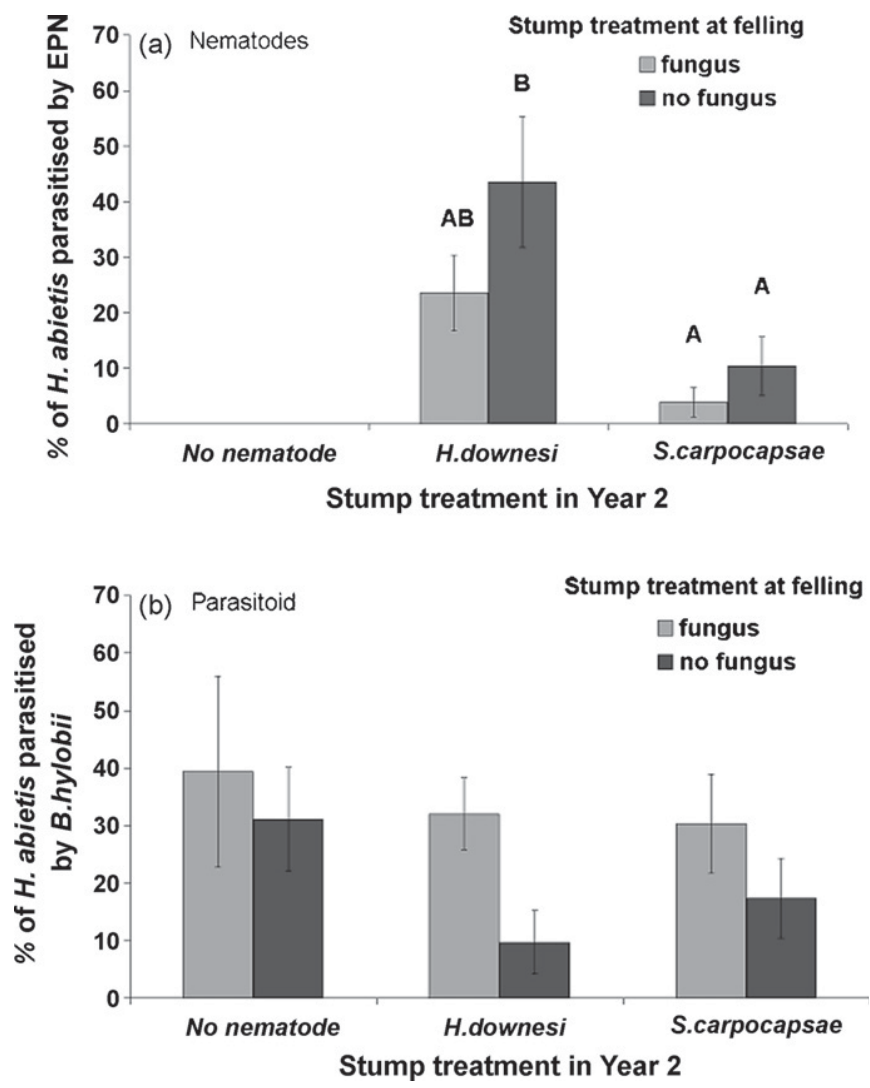

Fig. 2. Percentage (mean \pm S.E.) of Hylobius abietis parasitised by (a) entomopathogenic nematodes (Steinernema carpocapsae and Heterorhabditis downesi), or (b) the parasitic wasp B. hylobii at Annalecka in spruce stumps to which a wood-colonising fungus (Trichoderma koningii) was or was not applied at the time of felling. Nematode-treated stumps received 3.5 million nematodes/stump 23 months after felling and were destructively sampled 1 month later. Columns that share a letter are not significantly different (Tukey at $P=0.05$, following ANOVA, $P<0.05) . N=5$ stumps.

percentage of weevils attacked by EPN was again slightly lower in fungal-treated stumps than in no-fungus stumps $(H$. downesi $35.6 \pm 9.3$ and $46.0 \pm 11.0 ;$ S. carpocapsae $6.8 \pm 4.7$ and $13.3 \pm 6.4)$. Nematode species again had a significant effect on the percentage of weevils parasitised $\left(F_{1,16}=16.12\right.$, $P=0.001)$, but the fungus did not $\left(F_{1,16}=1.40, P=0.25\right)$. Nematode and fungus treatments did not interact significantly $\left(F_{1,16}=0.02, P=0.88\right)$.

In contrast to the EPN, there was a trend for B. hylobii to parasitise more weevils in fungal-treated stumps compared to stumps that were not treated with the fungus. This trend was seen irrespective of whether the stumps were also treated with nematodes (Fig. 2b). The effect of the fungus on parasitism by $B$. hylobii was significant at the $10 \%$ level $\left(F_{1,24}=3.77\right.$, $P=0.06)$. The effect of the nematodes was not significant $\left(F_{2}\right.$, $\left.{ }_{24}=1.59, P=0.22\right)$, and there was no interaction between the nematodes and the fungus $\left(F_{2,24}=0.39, P=0.68\right)$. When only those weevils that were not parasitised by EPN were considered, the percentage attacked by $B$. hylobii was again higher in stumps treated with the fungus than in those that were not for both $H$. downesi $(42.99 \pm 8.13$ and $13.1 \pm 6.5)$ and $S$. carpocapsae $(32.2 \pm 9.4$ and $20.0 \pm 7.7)$. The effect of the fungus was again significant at the $10 \%$ level $\left(F_{1,26}=3.04\right.$, 


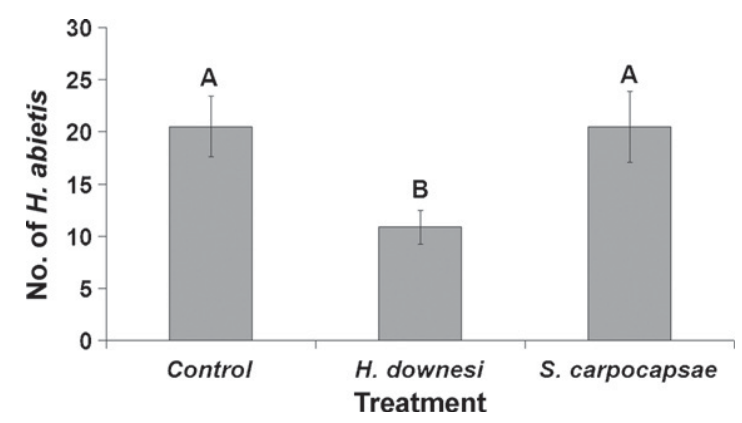

Fig. 3. Number (mean \pm S.E.) of Hylobius abietis adults emerging from spruce stumps. Emergence was recorded over a period of 63-65 weeks after nematode application. Nematodes were applied 18 or 23 months after felling. Different letters indicate significant differences between treatments (Tukey at $P=0.05$, following ANOVA, $P<0.05)$. $N=36$ stumps.

$P=0.09)$. The effect of nematodes was not significant $F_{1}$, $\left.{ }_{26}=1.64, P=0.21\right)$, and there was no interaction between nematodes and the fungus $\left(F_{1,26}=0.32, P=0.58\right)$.

\subsection{Effect of EPN on H. abietis emergence}

The number of adult $H$. abietis emerging from stumps was monitored over 2 seasons at Ballinagee and Oakwood. Numbers were significantly affected by stump treatment $(H$. downesi, $S$. carpocapsae or control) and site $\left(F_{2,102}=5.93\right.$, $P<0.01$ and $F_{1,102}=31.16, P<0.001$, respectively), and there was no interaction between these two factors $\left(F_{2}\right.$, $102=1.75, P>0.05)$. Fewer adult $H$. abietis emerged from $H$. downesi-treated stumps $(11 \pm 2)$ than from $S$. carpocapsaetreated $(21 \pm 3)$ and control stumps $(21 \pm 3)(P<0.05) . S$. carpocapsae did not reduce the number of adult $H$. abietis compared to control stumps $(P>0.05)$ (Fig. 3).

\subsection{Effect of T. koningii and EPN on H. abietis emergence (glendalough)}

The number of adult $H$. abietis emerging from untreated control stumps at Glendalough was very low during the first season of trapping $(5 \pm 2)$, and so was not continued for a second season. There was no significant difference between any of the treatments on this site (S. carpocapsae, H. downesi and T. koningii alone and in combination, and controls) (KruskalWallis Test, $H=1.61,5$ d.f., $P=0.90$ ).

\section{Discussion}

Conifer branches, or stumps, treated with $P$. gigantea reportedly deter oviposition by $H$. abietis, and are unsuitable as a medium for larval development (Skrzecz, 1996; Skrzecz and Moore, 1997). P. gigantea has not been recovered in Ireland, and the deployment of this non-indigenous fungus was therefore considered unsuitable in these trials. Similar effects on $H$. abietis have been associated with the presence of several other wood colonising fungi (some of them tree pathogens), including $H$. annosum, Armillaria mellea Kummer and $T$. harzianum (Crooke and Kirkland, 1956; Skrzecz and Moore,
1997). The fungus used in our trials (T. koningii) was chosen based on its negative impact on pine weevil development and repellence of adults in laboratory assays (Creevey, 1999). The low impact on weevil numbers in our field trials compared to trials with $P$. gigantea may reflect a difference in modes of action of the two fungi; $P$. gigantea is a wood rot fungus typically causing severe decomposition of stumps, while Trichoderma species are superficial decay fungi not associated with major structural decay of wood. A bottom-up approach to managing populations of $H$. abietis using $T$. koningii as a stump treatment was unsuccessful at directly reducing the number of weevils developing in the stumps. Nevertheless, stumps treated with $T$. koningii clearly differed from untreated ones in two respects: (1) weevils developed faster in them, and (2) the success of natural enemies was affected.

Stumps treated with $T$. koningii had higher levels of parasitism by $B$. hylobii than stumps that did not receive fungus $(P=0.06)$, while for entomopathogenic nematodes the trend $(P=0.08)$ was reversed. $T$. koningii produces secondary metabolites with antimicrobial and antibiotic activity (Sivasithamparam and Ghisalberti, 1998), so may have altered the stump mycoflora. As T. koningii does not cause major structural changes to timber, elevated numbers of B. hylobii are more likely to be due to changes in the volatiles emitted from the stump and/or the weevils in it, rather than due to major alterations in the physical structure of the stump. Indirect effects through the fungus altering the competitive balance between the natural enemies must also be considered.

Host finding by parasitoids and EPN involves a series of steps concerned with location of host habitat, the seeking out of host individuals within the habitat, and the acceptance of hosts for oviposition (Vinson, 1981; Lewis et al., 2006). B. hylobii responds to the stimuli associated with $H$. abietis larvae actively feeding on bark (Faccoli and Henry, 2003). Changes in the quality of either the bark or the weevil could affect their attractiveness for the parasitoid. Results show that age structure of $H$. abietis was altered by $T$. koningii. If $H$. abietis in the fungal-treated stumps developed faster, then it is possible that B. hylobii favoured these stumps as they contained larger larvae, which is the preferred host for the parasitoid (Henry and Day, 2001a). If T. koningii adversely affected weevil quality then it is possible that either female parasitoids deposited fewer eggs on each host, but compensated by allocating their eggs across more weevils, or weevil larvae were in a weakened state, and therefore more susceptible to parasitism (Henry and Day, 2001a,b; Awmack and Leather, 2002). Unfortunately data were not collected on the size of either weevil larvae or parasitoid clutches.

Armendariz et al. (2002) reported that inoculation of timber with $P$. gigantea enhanced invasion of insects by $S$. carpocapsae, but reduced invasion by Heterorhabditis megidis Poinar, Jackson and Klein. In our trials, inoculation of stumps with T. koningii at felling did not facilitate either $S$. carpocapsae or H. downesi applied 24 months later, indeed, infection levels were somewhat reduced as noted above. The facilitation of EPN reported by Armendariz et al. (2002) may have been due to the degradation of $P$. gigantea-treated wood- 
a structural change that the superficial decay fungus T. koningii would not be expected to induce.

T. koningii had the opposite effect on B. hylobii and entomopathogenic nematodes at Annalecka, suggesting that it affected the outcome of competition between these natural enemies. Both utilise weevil larvae (B. hylobii exclusively), for which they must compete. In our field trial, the trend for reduced parasitism of $H$. abietis by EPN in stumps treated with T. koningii was not evident when weevils parasitised by $B$. hylobii were treated as unavailable. It is not possible to say with certainty what proportion of the weevils was already unavailable to nematodes due to parasitism by $B$. hylobii at the time of EPN application. Stump assessment represents a snap-shot in time, four weeks after nematodes were applied. The B. hylobii population at the time of assessment included empty cocoons, intact cocoons and clutches of larvae that were still actively feeding. At $20^{\circ} \mathrm{C} \mathrm{B}$. hylobii eggs hatch within 1-2 days and larvae feed for about 7 days before initiating cocoon development. Most larvae pupate around 7 days after initiation of the cocoon stage. The pupal stage lasts around 7 days, after which time adults emerge from cocoons (Henry, 1995). B. hylobii generation time is almost twice as long at $15^{\circ} \mathrm{C}$ as at $20{ }^{\circ} \mathrm{C}$ (38 and 20 days, respectively), and the proportion of parasitoid larvae entering diapause instead of developing immediately increases from 63 to $100 \%$ as temperature decreases from 20 to $10{ }^{\circ} \mathrm{C}$ (Henry and Day, 2001a). It is likely that the $B$. hylobii recovered in these trials represent two generations: some of the empty cocoons were probably those of an overwintering generation which emerged between May and July (Henry, 1995), and the weevils on which they developed would certainly have been unavailable to nematodes, while the remainder, especially the active larvae and uneclosed cocoons were probably laid by the overwintering generation of Bracon since they emerged. Weevils on which B. hylobii have completed feeding and have cocooned are completely exhausted and unsuitable for nematode invasion; however, weevils on which $B$. hylobii larvae are still feeding can be invaded by entomopathogenic nematodes for up to 7 days (Armendariz, Henry and Griffin, unpublished data). As some of the B. hylobii were still larvae at the time of stump assessment, not all of the weevils harbouring the parasitoid at that time can be considered unavailable to EPN; the number of weevils available to EPN must in fact be an intermediate value between the total number of insects in a stump and the number not parasitised by $B$. hylobii.

In addition to competing for weevil hosts, B. hylobii and entomopathogenic nematodes are themselves in a potential host-parasite relationship (Georgis and Hague, 1982; Powell and Webster, 2004; Lacey et al., 2003). In the laboratory, developing B. hylobii are highly susceptible to EPN up until the time that the cocoon is spun (Everard, Griffin and Dillon, unpublished). Adult B. hylobii are also highly susceptible to EPN (Everard, Griffin and Dillon, unpublished), so parasitoids emerging from or visiting a nematode-treated stump to oviposit may have been killed. Despite susceptibility of the adult parasitoids to EPN, the percentage of weevils parasitised by $B$. hylobii was not reduced in nematode-treated stumps. In addition to killing individual parasitoids, nematodes might negatively impact on parasitoid populations if the female parasitoid lays her eggs on nematode-infected weevils where they are unable to complete their development. This is unlikely, as female $B$. hylobii will not oviposit on insects that have been killed by EPN, and tend to avoid ones that have been recently infected but have not yet died (Everard, Griffin and Dillon, unpublished). Such avoidance of oviposition on insect hosts infected with EPN is adaptive for the parasitoid and enhances the complementary effect of EPN for pest suppression (Lacey et al., 2003), since parasitoids may "mop up" weevils that are not hit by nematodes. Although there is evidence of competition between EPN and B. hylobii at Annalecka, this was not a general feature across all three sites. Addition of EPN (especially $H$. downesi) increased total parasitism of weevils over and above that caused by B. hylobii, indicating that the effects may be additive for this species at least.

Both $H$. downesi and $S$. carpocapsae perform less well in spruce than in pine, parasitising on average 30 and $10 \%$ in spruce (present trials), compared to 59 and $30 \%$ in pine (Dillon et al., 2006). Brixey (2000) also reported that parasitism by $S$. carpocapsae was lower in spruce than in pine $(21 \%$ versus $51 \%$, respectively), and suggested that the greater degree of bark degradation in pine facilitated nematode access to the weevils. The distribution of immature $H$. abietis within the stumps may also contribute to the lower levels of parasitism in spruce: $H$. abietis tend to be distributed further out along the roots in spruce than in pine (Brixey, 2000; Dillon et al., 2006), and parasitism of $H$. abietis by EPN decreases with increased distance out along the roots (Dillon et al., 2006, 2007). The possible role of diet in influencing the probability of infection by EPN (Barbercheck, 1993) has not been explored for immature $H$. abietis feeding on different conifer species. Sitka spruce stumps are considered less suitable than pine as breeding sites for $H$. abietis with fewer eggs laid, higher larval mortality and slower larval development (von Sydow and Birgersson, 1997; Bakke and Lekander, 1965; Thorpe and Day, 2002), therefore healthier insects developing at a higher density in pine may be more attractive to EPN, both individually and by producing a higher concentration of host volatiles.

\section{Conclusions}

Gross et al. (2005) analysed 828 records of biological control successes and failures using a regression based solely on trophic level variables, and concluded that bottom-up factors strongly influenced parasitoid-host population dynamics. In these trials a top-down approach using entomopathogenic nematodes reduced H. abietis populations developing in the stumps. Although a bottom-up approach using $T$. koningii as a stump treatment did not directly reduce $H$. abietis populations, the accelerated development of $H$. abietis, and the increased parasitism of $H$. abietis by $B$. hylobii in fungal-treated stumps suggest that stump modification should still be considered as a potential management tool for reducing $H$. abietis populations. Over all three sites EPN did not reduce parasitism by $B$. hylobii, suggesting that inundative application of EPN to stumps will not negatively 
impact on the principal natural enemy of $H$. abietis, and in fact the effect may be additive.

\section{Acknowledgments}

Nematodes were applied under licence (TA003/01) from the Pesticide Control Services of the Irish Department of Agriculture and Food. Research was funded by the National Council for Forest Research and Development (COFORD) through the Irish National Development Plan 2001-2006. Authors are grateful to Coillte Teoranta and the National Parks and Wildlife Service for provision of sites.

\section{References}

Armendariz, I., Downes, M.J., Griffin, C.T., 2002. Effect of timber condition on parasitization of pine weevil (Hylobius abietis L.) larvae by entomopathogenic nematodes under laboratory conditions. Biocontrol Sci. Technol. 12, 225-233.

Awmack, C.S., Leather, S.R., 2002. Host plant quality and fecundity in herbivorous insects. Annu. Rev. Entomol. 47, 817-844.

Bakke, A., Lekander, B., 1965. Studies on Hylobius abietis L. 2. Meddelelse fra det Norske Skogforsoksvesen 20, 117-135.

Barbercheck, M.E., 1993. Tritrophic level effects on entomopathogenic nematodes. Environ. Entomol. 22, 1166-1171.

Berglund, M., Ronnberg, J., Homer, L., Stenlid, J., 2005. Comparison of five strains of Phlebiopsis gigantea and two Trichoderma formulations for treatment against natural Heterobasidion spore infections in Norway spruce stumps. Scand. J. Forest Res. 20, 12-17.

Brixey, J., 2000. The use of entomopathogenic nematodes to control the immature stages of the large pine weevil, Hylobius abietis. Ph.D. Thesis, University of Reading, UK, $188 \mathrm{pp}$.

Brixey, J.M., Moore, R., Milner, A.D., 2006. Effect of entomopathogenic nematode (S. carpocapsae Weiser) application technique on the efficacy and distribution of infection of the large pine weevil (Hylobius abietis L.) in stumps of Sitka spruce (Picea sitchensis Carr) created at different times. Forest Ecol. Manage. 226, 161-172.

Creevy, J.C., 1999. Fungal colonisers of coniferous stumps as deterrents of the Large European Pine Weevil (Hylobius abietis L.) M.Sc. Thesis. National University of Ireland Maynooth, Ireland, $58 \mathrm{pp}$.

Crooke, M., Kirkland, R.C., 1956. The gale of 1954: an appraisal of its influence on forest populations in pine areas. Scottish Forestry 10, 135-145.

Dillon, A.B., Ward, D., Downes, M.J., Griffin, C.T., 2006. Suppression of the large pine weevil Hylobius abietis (Coleoptera: Curculionidae) in pine stumps by entomopathogenic nematodes with different foraging strategies. Biol. Control 38, 217-226.

Dillon, A.B., Downes, M.J., Ward, D., Griffin, C.T., 2007. Optimizing application of entomopathogenic nematodes to manage large pine weevil, Hylobius abietis L. (Coleoptera: Curculionidae) populations developing in pine stumps, Pinus sylvestris. Biol. Control 40, 253-263.

Eidmann, H.H., 1979. Integrated management of pine weevil (Hylobius abietis L.) populations in Sweden. US Dept. Agriculture and Forestry Service General Technical Report, WO-8, pp. 103-109.

Elton, E.T.G., Blankwaardt, H.F.H., Burger, H.C., Steemers, W.F., Tichelman, L.G., 1964. Insect communities in barked and unbarked pine stumps, with special reference to the large pine weevil (Hylobius abietis L., Col., Curculionidae). J. Appl. Entomol. 55, 1-54.

Faccoli, M., Henry, C.J., 2003. Host location by chemical stimuli in Bracon hylobii (Ratzeburg) (Hymenoptera: Braconidae) a larval parasitoid of Hylobius abietis (L.) (Coleoptera: Curculionidae). Ann. Soc. Entomol. France 39, 247-256.

Forst, S., Dowds, B., Boemare, N., Stackebrandt, E., 1997. Xenorhabdus and Photorhabdus spp: bugs that kill bugs. Annu. Rev. Microbiol. 51, 47-72.
Georgis, R., Hague, N.G.M., 1982. Interactions between Neoaplectana carpocapsae (Nematode) and Olesicampe monticola, a parasitoid of the larch sawfly Cephalcia lariciphila. IRCS Med. Sci. 10, 617.

Grewal, P.S., Ehlers, R.U., Shapiro-Ilan, D.J., 2005. Nematodes as Biocontrol Agents. CABI Publishing, Wallingford, UK, p. 480.

Gross, P., Hawkins, B.A., Cornell, H.V., Hosmane, B., 2005. Using lower trophic level factors to predict outcomes in classical biological control of insect pests. Basic Appl. Ecol. 6, 571-584.

Henry, C., 1995. The effect of a braconid ectoparasitoid, Bracon hylobii Ratz., on larval populations of the large pine weevil, Hylobius abietis L. Ph.D. Thesis. University of Ulster at Coleraine, UK, $199 \mathrm{pp}$.

Henry, C.J., Day, K.R., 2001a. Egg allocation by Bracon hylobii Ratz., the principal parasitoid of the large pine weevil (Hylobius abietis L.) and implications for host suppression. Agric. Forest Entomol. 3, 11-18.

Henry, C.J., Day, K.R., 2001b. Biocontrol of the large pine weevil: structure of host (Hylobius abietis L.) and parasitoid (Bracon hylobii Ratz.) populations in felled stumps of sitka spruce. In: Alfaro, R.I., Day, K., Salom, S., Nair, K.S.S., Evans, H., Liebhold, A., Lieutier, F., Wagner, M., Futai, K., Suzuki, K. (Eds.), Protection of World Forests from Insect Pests: Advances in Research. IUFRO World Series, vol. 11. IUFRO Secretariat, Vienna, pp. 112.

Heritage, S., Moore, R., 2001. The assessment of site characteristics as part of a management strategy to reduce damage by Hylobius. Information Note 38 . Forestry Commission, Edinburgh, UK, 6 pp.

Holdenrieder, O., Greig, B.J.W., 1998. Biological methods of control. In: Woodward, S., Steinlid, J., Karjalainen, R., Huttermann, A. (Eds.), Heterobasidion annosum

Jaworska, M., 1998. The laboratory preference of annual legumes by pea weevil Sitona lineatus L. (Col., Curculionidae) and their effect on susceptibility of weevils to entomopathogenous nematodes. J. Invertebrate Pathol. 71, 248250

Kallio, T., Hallaksela, A.M., 1979. Biol. Control of Heterobasidion annosum (Fr.) Bref. (Fomes annosus) in Finland. Eur. J. Forest Pathol. 9, 298-308.

Kenis, M., Wegensteiner, R., Griffin, C.T., 2004. Parasitoids, predators, nematodes and pathogens associated with bark weevil pests. In: Lieutier, F., Day, K.R., Battisti, A., Gregoire, J.C., Evans, H.F. (Eds.), Bark and Wood Boring Insects in Living Trees in Europe, a Synthesis. Kluwer Academic Publishers, Dordrecht, Netherlands, pp. 395-414.

Klein, D., Eveleigh, D.E., 1998. Ecology of Trichoderma. In: Kubicek, C.P. Harman, G.E. (Eds.), Trichoderma and Gliocladium. Vol. 1. Basic Biology, Taxonomy and Genetics. Taylor and Francis Ltd., London, UK, pp. 57-74.

Kruse, J.J., Raffa, K.F., 1999. Effect of food plant switching by the herbivore on its parasitoid: Cotesia melanoscela development in Lymantria dispar exposed to reciprocal dietary crosses. Ecol. Entomol. 24, 37-45.

Lacey, L.A., Unruh, T.R., Headrick, H.L., 2003. Interactions of two idiobiont parasitoids (Hymenoptera: Ichneumonidae) of codling moth (Lepidoptera: Tortricidae) with the entomopathogenic nematode Steinernema carpocapsae (Rhabditida: Steinernematidae). J. Invertebrate Pathol. 83, 230-239.

Langstrom, B., Day, K.R., 2004. Damage control and management of weevil pests, especially Hylobius abietis. In: Lieutier, F., Day, K.R., Battisti, A. Gregoire, J.C., Evans, H.F. (Eds.), Bark and Wood Boring Insects in Living Trees in Europe, a Synthesis. Kluwer Academic Publishers, Dordrecht, Netherlands, pp. 415-444.

Lewis, E.E., Campbell, J., Griffin, C., Kaya, H., Peters, A., 2006. Behavioral ecology of entomopathogenic nematodes. Biol. Control 38, 66-79.

Minitab Inc., 2003. MINITAB Statistical Software, Release 14 for Windows. State College, PA, USA.

Nicolotti, G., Varese, G.C., 1996. Screening of antagonistic fungi against airborne infection by Heterorbasidion annosum on Norway spruce. Forest Ecol. Manage. 88, 249-257.

Nordlander, G., 1987. A method for trapping Hylobius abietis (L.) larvae with a standardised bait and its potential for forecasting seedling damage. Scand. J. Forest Res. 2, 199-213.

Nordlander, G., Eidmann, H.E., Jacobsson, U., Nordenhem, H., Sjodin, K., 1986. Orientation of the pine weevil Hylobius abietis to underground sources of host volatiles. Entomol. Exp. Appl. 41, 91-100.

Norlander, G., Nordenhem, H., Bylund, H., 1997. Oviposition patterns of the pine weevil Hylobius abietis. Entomol. Exp. Appl. 85, 1-9. 
Okland, B., Berryman, A., 2004. Resource dynamics plays a key role in regional fluctuations of the spruce bark beetles Ips typographus. Agric. Forest Entomol. 6, 141-146.

Powell, J.R., Webster, J.M., 2004. Interguild antagonism between biological controls: impact of entomopathogenic nematode application on an aphid predator Aphidoletes aphidimyza (Diptera: Cecidomyiidae). Biol. Control 30, 110-118.

Price, P.W., Bouton, C.E., Gross, P., McPheron, B.A., Thompson, J.N., Weis, A.E., 1980. Interactions among three trophic levels: influence of plants on interactions between insect herbivores and natural enemies. Annu. Rev. Ecol. Syst. 11, 41-65.

Sivasithamparam, K., Ghisalberti, E.L., 1998. Secondary metabolites in Trichoderma and Gliocladium. In: Kubicek, C.P., Harman, G.E. (Eds.), Trichoderma and Gliocladium

Skrzecz, I., 1996. Impact of Phlebia gigantea (Fr.:Fr) Donk on the colonization of Scots pine (Pinus sylvestris L.) stumps by the large pine weevil (Hylobius abietis L.). Folia Forestalia Polonica 38, 89-101.

Skrzecz, I., Moore, R., 1997. The attractiveness of pine branches infected with selected wood colonizing fungi to the large pine weevil (Hylobius abietis). In: Gregoire, J.C., Liebhold, A.M., Stephen, F.M., Day, K.R., Salom, S.M. (Eds.). Integrating cultural tactics into the management of bark beetle and reforestation pests. USDA Forest Service Technical Report NE 236, pp 146-152.

Thorpe, K.V., Day, K.R., 2002. The impact of host plant species on the larval development of the large pine weevil Hylobius abietis L. Agric. Forest Entomol. 4, 187-194.

Torr, P., Wilson, M.J., Heritage, S., 2005. Forestry applications. In: Grewal, P.S., Ehlers, R.U., Shapiro-Ilan, D.J. (Eds.), Nematodes as Biocontrol Agents. CABI Publishing, Wallingford, UK, pp. 281-294.

Torr, P., Heritage, S., Wilson, M.J., 2007. Steinernema kraussei, an indigenous nematode found in coniferous forests: efficacy and field persistence against Hylobius abietis. Agric. Forest Entomol. 9, 181-188.

Vinson, S.B., 1981. Habitat location. In: Nordlund, D.A., Jones, R.L., Lewis, W.L. (Eds.), Semiochemicals: Their Role in Pest Control. John Wiley and Sons, New York, USA, pp. 417-469.

von Sydow, F., Birgersson, G., 1997. Conifer stump condition and pine weevil (Hylobius abietis) reproduction. Can. J. Forest Res. 27, 1254 1262.

Woodring, J.L., Kaya, H.K., 1988. Steinernematid and Heterorhabditid Nematodes: A Handbook of Techniques. Southern Cooperative Series Bulletin, vol. 331. Arkansas Agricultural Experiment Station, Fayetteville, AR, USA, $30 \mathrm{pp}$. 